\title{
On feeding and helminth fauna of neon flying squid Ommastrephes bartramii (Lesueur, 1821) (Cephalopoda: Ommastrephidae) in the southeastern Pacific
}

\author{
Alimentación y fauna de helmintos del calamar rojo Ommastrephes bartramii (Cephalopoda: \\ Ommastrephidae) en el Pacífico sudeste
}

\section{Chingis M. Nigmatullin ${ }^{1}$, Alexander S. Shchetinnikov ${ }^{1}$ and Olga A. Shukhgalter ${ }^{1}$}

\author{
${ }^{1}$ Atlantic Research Institute of Marine Fisheries and Oceanography (AtlantNIRO), Donskoj Str. 5, Kaliningrad, 236000 Russia \\ squid@atlant.baltnet.ru
}

\begin{abstract}
Resumen.- Se analizó el contenido estomacal de 60 calamares Ommastrephes bartramii (160-392 mm mantle length, ML) recolectados en el Pacífico sudeste (entre $17^{\circ} \mathrm{y}$ $43^{\circ} \mathrm{S}$ ), entre 1981 y 1984 . Adicionalmente otros 22 calamares (165-365 mm ML) fueron examinaron por parásitos helmintos. Las principales presas fueron peces mictófidos (Symbolophorus evermanni, Myctophum nitidilum, M. phengodes, Hygophum reinhardti, H. proximum), Diplospinus multistriatus, Argyropelecus affinis y juveniles de Exocoetidae. Los calamares (principalmente Onychoteuthis banksi y Abraliopsis affinis) y los camarones, fueron presas secundarias, mientras que eufáusidos, anfípodos, moluscos octópodos y heterópodos fueron presas accidentales. El tamaño de las presas fue entre 8 y $440 \mathrm{~mm}$, con un tamaño relativo de 3,2-77,2\% de longitud absoluta (AL=ML + longitud de la cabeza y del brazo mas largo), mayoritariamente de 8-20\% AL. El alimento en el estómago de las presas, principalmente mictófidos, se presentó
\end{abstract}

\section{Introduction}

The dominant oceanic nektonic squid Ommastrephes bartramii (Lesueur, 1821) is very widely distributed throughout the subtropical and lower-laltitude temperate zones of both hemispheres of the world ocean (Nesis, 1987). Its role in structure and functioning of the oceanic ecosystems is important, and has been the subject of study for the last three decades. However, geographical differences between feeding and parasitological characteristics of this species have not been extensively studied. The feeding ecology and helminth fauna was studied in the North Pacific (Shevtsov 1972, Wormuth 1976, Naito et al. 1977, Bower \& Margolis 1991, Sinclair 1991, Seki 1993, Nagasawa et al. 1998, Watanabe et al. 2004, Bower \& Ichii 2005, Young 2005, Parry 2006, 2008), the North and South Atlantic (Gaevskaya \& en el 43,3\% de los estómagos e incluyó copépodos, ostrácodos, anfípodos, eufáusidos, camarones, moluscos tecosomados, heterópodos y quetognatos. Se encontraron seis especies de helmintos parásitos en estado larval, con una prevalencia total de infección de 90,9\%: los cestodos Tentacularia coryphaenae (prevalencia: 9,1\%, rango de intensidad: 2-3), Scyphophyllidium sp. $(4,5 \%, 12)$; el tremátodo no identificado de Didymozoidae (86,4\%, 6-1500); los nemátodos Anisakis physeteris (18,2\%, 1-9), Porrocaecum sp. (36,3\%, 1-21) y Contracaecum sp. (13,6\%, 1-114). Sus ciclos de vida ocurren en cadenas tróficas de las comunidades pelágicas y los calamares se infectarían al comer crustáceos parasitados. Ommastrephes bartramii es un huésped transportador para las especies de helmintos estudiadas, cuyos huéspedes definitivos serían peces óseos (scombroideos y xifoideos), tiburones, mamíferos marinos y aves marinas.

Palabras clave: Hábitos de alimentación, fauna de helmintos

\footnotetext{
${ }^{1}$ Nigmatullin ChM \& MA Pinchukov. 1976. The feeding of Bartram squid Ommastrephes bartrami Les. in the Atlantic Ocean and Mediterranean Sea. In: AtlantNIRO conference 'Problems of investigation of pelagic fish and invertebrates of the Atlantic Ocean'. Abstracts of communications. AtlantNIRO Press, Kaliningrad, p. 20. [In Russian]
} 


\section{Material and methods}

Squids used for this study were collected during 19811984 aboard AtlantNIRO research vessels at nightlighting drift stations in the south part of the eastern Pacific (Fig. 1). The squids were caught with hand jigs. The squid were immediately frozen after capture and examined for food and helminths 4-6 months later. Squid were analyzed with identification of dorsal mantle length (ML), absolute length (AL), sex, stage of maturity and stomach fullness (six-point scale by Zuev et al. 1985).

\section{Feeding}

Squids used for the food composition study were collected in the area between $17-32^{\circ} \mathrm{S}$ and $79-95^{\circ} \mathrm{W}$ in April 1981, July and November-December 1982 and January 1984 (Fig. 1). Stomach contents were studied on 60 squids of ML 160-392 mm including 40 squids with full stomachs (fullness degree 3-5). From the total squids, 56 were males of ML 160-392 mm and 4 were females of ML 166-240 $\mathrm{mm}$. Crustacean food items were identified by eyes, mandibles, maxillipeds, thoracic limbs and chitinous integuments; cephalopods were determined by beaks,

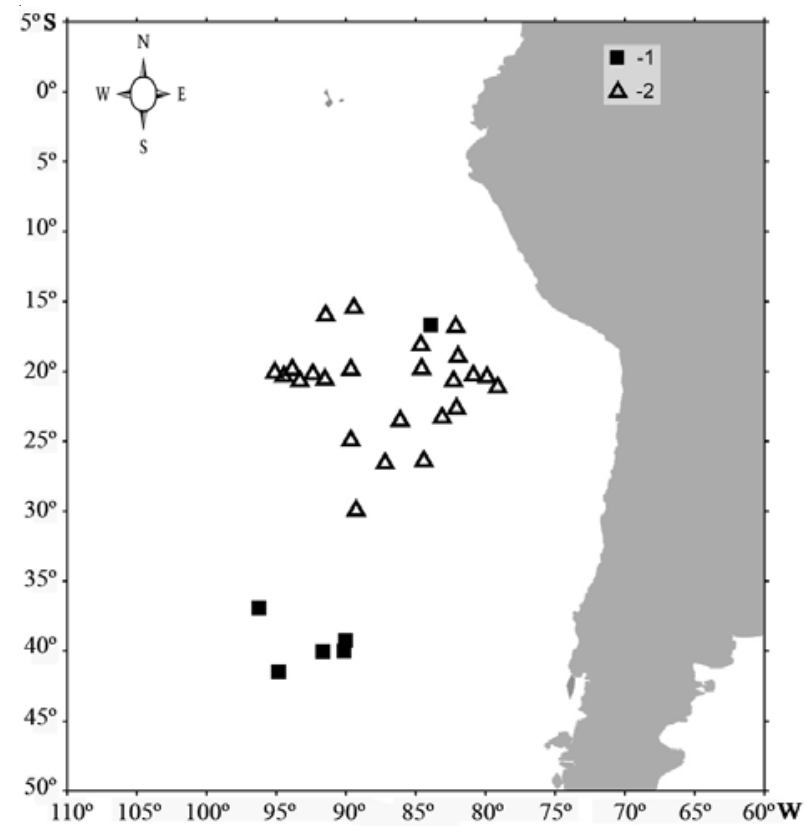

Figure 1

Distribution of stations in southeastern Pacific where Ommastrephes bartramii squids were collected for parasitological (1) and feeding (2) investigations

Distribución de estaciones en el Pacífico sudeste donde se recolectaron los calamares Ommastrephes bartramii para las investigaciones parasitológicas (1) y de alimentación (2) horny rings of suckers and hooks; heteropods were identified by radular hooks; whereas fishes were identified by otoliths, scales and bony elements (Zuev et al. 1985). The identification of fish remains was based on published description according to the main diagnostic traits of osteological elements of pelagic fishes of the southeastern Pacific (Topal 1988). Estimate of fish body size were made from data on bony elements and otolith length against fish body size (Topal 1988). The body size reconstruction of crustacean and cephalopods were made by index of length of hard test elements relative to size of these animals. The relative prey size (RPS) was estimated as ratio (in \%) of prey length to absolute squid length (\%AL). AL is measured from mantle end to tip of longest arm (Zuev et al. 1985). AL of the studied O. bartramii of ML 160-392 mm was 170-175\% ML.

Total number of prey by specific hard body elements was estimated in each stomach. In addition we distinguished a special food group - transit (secondary) food. It is not eaten directly by predator, but it get into predator's stomach after eating of the proper food organism with viscera (Nigmatullin \& Toporova 1982, Nigmatullin 2005a,b). To estimate the role of each food component, the frequency of occurrence (percentage of stomachs containing food) and proportion of volume of full stomach contents (percentage of volume of stomach content) were calculated (Zuev et al. 1985).

\section{Helminths}

Parasitic helminths were obtained from 22 squid of ML 165-365 mm that were collected in the area between 17$43^{\circ} \mathrm{S}$ and $78-95^{\circ} \mathrm{W}$ in April 1981, January and July-August 1984. This sample was subdivided into two sub-samples according two areas of catch (Fig. 1): 1) $17-20^{\circ} \mathrm{S}$ and 80 $84^{\circ} \mathrm{W}$ ( $\mathrm{n}=14$ of ML $165-365 \mathrm{~mm}$ ) and 2) $34-43^{\circ} \mathrm{S}$ and $78-95^{\circ} \mathrm{W}$ ( $\mathrm{n}=8$ of ML $240-360 \mathrm{~mm}$ ). The helminthological investigation of squids followed the standard methods (Zuev et al. 1985). All worms were collected from defrosted squids. Trematodes and cestodes were fixed in $10 \%$ formalin and stored in $70 \%$ alcohol. These worms were stained in alum carmine after washing in distilled water, dehydrated in alcohol, cleared in oil cloves and mounted in Canada balsam. Nematodes were preserved in formalin and cleared in mixture of glycerol and lactic acid. The larvae of cestodes were identified following descriptions by Yamaguti (1959) and Palm (2004), didymozoid trematodes by Hochberg (1990) and anisakid nematodes by Berland (1961) and Smith (1983). The parasitological descriptors, such as prevalence and intensity were used in accordance to Margolis et al. (1982). 


\section{Results}

\section{Feeding}

The food spectrum was wide. It included 2 species of amphipods, 2 euphausiids, 4 shrimps, 1 heteropod, 2 pelagic octopods, 12 squids and 29 teleosts including 17 species of Myctophidae and 10 species from 10 other families (Table 1).
The main foods were myctophids (S. evermanni, $M$. nitidilum, $M$. phengodes, $H$. reinhardti, $H$. proximum), Diplospinus multistriatus, Argyropelecus affinis and juveniles of Exocoetidae. Squids (mainly O. banksi and Abraliopsis affinis) and shrimps were secondary food. Euphausiids, amphipods, octopods and heteropod mollusks were accidental food. Of these, euphausiids and amphipods were found in stomachs of squids of $\mathrm{ML}<$ $200 \mathrm{~mm}$ only.

\section{Table 1}

\section{Food items of Ommastrephes bartramii in open waters of SE Pacific ( $\mathrm{N}=$ frequency of occurrence as percentage of stomachs containing food, $V=$ proportion of volume of full stomach contents)}

Ítems alimentarios de Ommastrephes bartramii en aguas oceánicas del Pacífico sudeste ( $\mathrm{N}=$ frecuencia de ocurrencia como porcentaje de estómagos conteniendo alimento, V=proporción del volúmen de estómagos llenos de contenido)

\begin{tabular}{|c|c|c|}
\hline Food groups & $\mathrm{N}(\%)$ & $\mathrm{V}(\%)$ \\
\hline Teleosts & 100.0 & 83.7 \\
\hline Myctophidae & 73.3 & 57.2 \\
\hline Symbolophorus evermanni & 11.6 & 10.5 \\
\hline Myctophum nitidulum & 16.6 & 7.0 \\
\hline Myctophum lychnobium & 3.3 & - \\
\hline Myctophum aurolaternatum & 1.7 & 2.0 \\
\hline Myctophum asperum & 1.7 & 2.2 \\
\hline Myctophum phengodes & 6.7 & 4.8 \\
\hline Myctophum sp. & 1.7 & 0.5 \\
\hline Hygophum reinhardtii & 18.3 & 6.2 \\
\hline Hygophum proximum & 8.3 & 4.5 \\
\hline Hygophum hygomii & 5.0 & 1.8 \\
\hline Notoscopelus resplendens & 5.0 & 0.8 \\
\hline Ceratoscopelus warmingii & 1.7 & - \\
\hline Gonichthys tenuiculus & 1.7 & 0.8 \\
\hline Diaphus meadi & 1.7 & - \\
\hline Benthosema suborbital & 3.3 & 2.0 \\
\hline Lampanyctus parvicauda & 1.7 & - \\
\hline Lampadena urophaos & 1.7 & - \\
\hline Unidentified Myctophidae & 15.0 & 13.5 \\
\hline Photichtyidae, Vinciguerria lucetia & 6.7 & 1.2 \\
\hline Gonostomidae & 5.0 & 0.3 \\
\hline Gonostoma sp. & 3.3 & 0.3 \\
\hline Diplophos taenia & 1.7 & - \\
\hline Chauliodontidae, Chauliodus sp. & 5.0 & 0.3 \\
\hline Sternoptychidae, Argyropelecus affinis & 8.3 & 4.0 \\
\hline Melanostomiatidae, Bathophilus fillifer & 1.7 & - \\
\hline Tetragonuridae, Tetragonurus atlanticus & 1.7 & 1.5 \\
\hline Gempylidae, Diplospinus multistriatus & 15.0 & 6.2 \\
\hline Idiacanthidae, Idiacanthus sp. & 5.0 & - \\
\hline Melamphaidae, Melamphaes sp. & 6.7 & 2.2 \\
\hline Exocoetidae & 8.3 & 6.5 \\
\hline Unidentified plankton-eating fishes & 5.0 & 1.8 \\
\hline Unidentified predatory fishes & 6.6 & 2.5 \\
\hline Cephalopoda & 46.7 & 13.8 \\
\hline Octopoda & 3.4 & - \\
\hline
\end{tabular}

\begin{tabular}{|c|c|c|}
\hline Food groups & $\mathrm{N}(\%)$ & $\mathrm{V}(\%)$ \\
\hline Ocytoe tuberculata & 1.7 & - \\
\hline Argonauta argo & 1.7 & - \\
\hline Teuthida & 45.0 & 13.8 \\
\hline Ommastrephidae & 3.3 & 3.7 \\
\hline Dosidicus gigas & 1.7 & 2.0 \\
\hline Ommastrephes bartramii & 1.7 & 1.7 \\
\hline Thysanoteuthidae, Thysanoteuthis rhombus & 1.7 & 1.2 \\
\hline Onychoteuthidae, Onychoteuthis banksi & 20.0 & 7.8 \\
\hline Enoploteuthidae & 18.3 & 0.8 \\
\hline Abraliopsis affinis & 8.3 & 0.8 \\
\hline Enoploteuthis sp. & 1.7 & - \\
\hline Pterygioteuthis giardi & 5.0 & - \\
\hline Ancistrocheirus alessandrinii & 1.7 & - \\
\hline Histioteuthidae, Histioteuthis sp. & 1.7 & - \\
\hline Cranchiidae & 3.4 & - \\
\hline Liocranchia reinhardti & 1.7 & - \\
\hline Teuthowenia megalops & 1.7 & - \\
\hline Unidentified Teuthida & 3.3 & 0.3 \\
\hline Mollusca, Heteropoda, Carinaria sp. & 1.7 & - \\
\hline Crustacea & 15.0 & 2.5 \\
\hline Decapoda & 8.3 & 2.5 \\
\hline Sergestes sp. & 3.3 & - \\
\hline Oplophorus spinosus & 5.0 & 2.5 \\
\hline Acanthephyra sp. & 1.7 & - \\
\hline Heterocarpus ensifer & 1.7 & - \\
\hline Euphausiacea & 6.6 & - \\
\hline Thysanopoda monocautha & 3.3 & - \\
\hline Euphausia sp. & 3.3 & - \\
\hline Amphipoda & 1.7 & - \\
\hline Phronimella elongate & 1.7 & - \\
\hline Parapronoe crusculum & 1.7 & - \\
\hline Phronima stebbingi & 1.7 & - \\
\hline Transit food items & 43.3 & - \\
\hline Number of stomachs & 60 & 40 \\
\hline
\end{tabular}


Prey size ranged from 8 to $440 \mathrm{~mm}$, and RPS from 3.2 to $77.2 \% \mathrm{AL}$. The mean values of absolute and relative prey size were $62 \mathrm{~mm}$ and 13.5\% AL. RPS values were mainly 8-20\% AL. Size of myctophid prey ranged from 17 to $112 \mathrm{~mm}$ (5.6-24\% AL) with average length of 55 $\mathrm{mm}(11.4 \% \mathrm{AL})$. The size of other fishes in O.bartramii diet was larger: 17-440 mm (4.7-77.2\% AL) with an average length $93 \mathrm{~mm}$ (21.5\% AL). The largest fish consumed was Diplospinus multistriatus with length 260$440 \mathrm{~mm}$ (46.1-77.2\% AL). This species has a narrow, fusiform body and squid of ML 280-320 mm may be capable of catching and eating them.

The AL of squid prey varied from 28 to $210 \mathrm{~mm}$ (4.3$61.7 \% \mathrm{AL}$ ) with mean value of $85 \mathrm{~mm}$ (18\% AL). The two largest squid prey were Dosidicus gigas and $O$. bartramii of ML $130-140 \mathrm{~mm}(\mathrm{AL}=210 \mathrm{~mm})$ with RPS of 61.7 and $42.4 \%$ AL respectively. The AL of Onychoteuthis banksi were 28-150 mm (4.3-40\% AL), Thysanoteuthis rhombus - $150 \mathrm{~mm}$ (40\%AL) and Enoploteuthidae - 30-100 mm (6-16.1\% AL). Crustaceans were the smallest prey: euphausiids - 6-35 mm (2.4-12.3\% AL), amphipods - 0.9-1.9 mm (3.2-6.7\% AL) and shrimps - 30-80 mm (9.3-13.1\% AL).

The total number of prey items per stomach varied widely from 1 to 19 specimens (mean 6). The number of recently eaten prey (with undigested soft tissues) varied from 1 to 18 (3.1). The maximum number of consumed myctophid specimens was 11 (mean 3.8), and their recently eaten number was 10 (2.5). Mean number of all eaten fishes was 5.5 and their recently eaten representatives - 3.7. The number squid prey ranged between 1 and 4 (mean 1.6) with 1.2 being recently eaten. The number of crustacean prey did not exceed 4 with a mean 1.9.

Transit food items occurred in $43.3 \%$ of stomachs. As rule transit food organisms were introduced into the studied squid stomach from the stomachs of prey, mainly plankton-eating fishes. They included copepods (Oithona sp., Oncea sp., Candacia sp., C. pachydactula, Calanus sp., Eucalanus sp.), ostracods, amphipods (Phrosina semilunata, Phronima stebbingi, Vibilia armata, Parapronoe crustulum), euphausiids (Euphausia sp., E.eximia, Stylocheiron sp.), shrimps (Sergestes sp.), thecosomaths (Peracle sp.), heteropods and chaetognaths. The number of transit food organisms varied between 1 and 20 (mean 5). Their size were significantly smaller than the proper food organisms and varied between 0.7 $22 \mathrm{~mm}$ (mean $5.4 \mathrm{~mm}$ ), and their RPS were 0.2-6.5\% AL with mean value $0.7 \%$ AL. There was some overlapping of maximal lengths of transit food organisms and minimal lengths of proper food, but this was infrequent and these organisms were very rare. Most of transit food organisms were from myctophid and other fish stomachs and, more infrequently, from squid stomachs.

\section{The helminth fauna}

Six species of parasitic helminths were found and all were in the larval stages (Table 2). The total prevalence of infection was $90.9 \%$.

Table 2

Data on prevalence, (P, \%) and range of intensity (I) of infections in Ommastrephes bartramii $(\mathbf{n}=22)$

Datos de prevalencia (P, \%) y rango de intensidad (I) de infecciones en Ommastrephes bartramii $(\mathrm{n}=22)$

\begin{tabular}{lll}
\hline Parasites: & P $(\%)$ & I \\
\hline Cestoda & & \\
$\quad$ Tentacularia coryphaenae & $9.1(2.6-29.4)^{*}$ & $2-3$ \\
Scyphophyllidium sp. & $4.5(0.8-23.2)$ & 12 \\
Trematoda & & \\
Didymozoidae (indetermined metacercariae) & $86.4(63.5-96.5)$ & $6-1500$ \\
Nematoda & & \\
Anisakis physeteris & $18.2(7.6-40.4)$ & $1-9$ \\
$\quad$ Porrocaecum sp. & $36.3(20.4-59.8)$ & $1-21$ \\
Contracaecum sp. & $13.6(12.9-27.1)$ & $1-114$ \\
\hline
\end{tabular}

* - in brackets - confidence limits 
Larvae of Scyphophyllidium sp. were found in the stomach cavity and caecum. The size range of 10 specimens was $0.31-0.70 \mathrm{~mm}$. Bothridia $(0.06-0.1 \mathrm{~mm})$ are attached along the full length, suckers are absent.

Larvae of $T$. coryphaenae were found within the whole mantle cavity including the internal organs, occasionally penetrating into the mantle wall. These worms are very mobile and able to actively migrate within the mantle cavity. The size range of 10 specimens was $3.6-14.0 \mathrm{~mm}$, maximum widths at the level of pars bothridialis 1.5-3.0 $\mathrm{mm}$. Larvae possess four tentacles armed with hooks. Armature was homeoacanthous homeomorphous with characteristic tridentate basal hooks. Size of metabasal hooks: $0.031 \mathrm{~mm}$, size of basal hooks: 0.01-0.014 mm. Pars bothridialis: $2.5-7.4 \mathrm{~mm}$, pars vaginalis: $1.0-2.0 \mathrm{~mm}$, pars bulbosa: $0.95-1.30 \mathrm{~mm}$, pars postbulbosa: 0.9-7.2 $\mathrm{mm}$, appendix: 0.7-4.78 $\mathrm{mm}$ and velum: 0.7-2.9 $\mathrm{mm}$.

Metacercariae of Didymozoidae were localized in cysts on the inner wall of the stomach mainly along blood vessels. The length range of 20 specimens was $0.43-0.71$ $\mathrm{mm}$, maximum widths $0.14-0.21 \mathrm{~mm}$. Oral sucker almost terminal $(0.02-0.05 \times 0.03-0.06 \mathrm{~mm})$. Ventral sucker (0.05-0.07 x 0.06-0.08 mm) larger than oral sucker. Ventral sucker situated just anterior to mid-body. Eighteen to twenty vesicular cells.

The third-stage larvae of A. physeteris were encysted in the stomach wall and mainly in gonad's coelomic membranes. The size range of 8 specimens was 6.4-7.8 $\mathrm{mm}$, maximum body width $0.22-0.23 \mathrm{~mm}$. Length from anterior end of body to nerve ring (position of nerve ring) $0.16-0.19 \mathrm{~mm}$. Length of oesophagus $0.86-0.98 \mathrm{~mm}$. Size of stomach $0.09-0.15 \times 0.15-0.26 \mathrm{~mm}$. Tail length $0.11-$ $0.12 \mathrm{~mm}$ and length of tail mucron $0.004 \mathrm{~mm}$.

Larvae of Porrocaecum were encysted in the stomach wall (length 3.5-6.4 mm) and into inner mantle wall (18.0$22.5 \mathrm{~mm}$ ). Measurements of small larvae based on 20 specimens. Maximum widths $0.11-0.27 \mathrm{~mm}$. Length from anterior end of body to nerve ring $0.10-0.14 \mathrm{~mm}$. Length of oesophagus $0.86-1.19 \mathrm{~mm}$, size of stomach $0.05-0.07$ $\mathrm{x}$ 0.11-0.17 mm and length of intestinal caecum 0.38$0.53 \mathrm{~mm}$. Excretory pore situated at the level of nerve ring. Tail length $0.13-0.14 \mathrm{~mm}$, length of tail thorn 0.01 $\mathrm{mm}$. Measurements of large larvae also based on 20 specimens. Maximum width 0.7-1.0 mm. Length from anterior end of body to nerve ring $0.27-0.38 \mathrm{~mm}$. Length of oesophagus 2.54-3.02 mm, size of stomach 0.20-0.23 $\mathrm{x}$ 0.31-0.34 mm and length of intestinal caecum 1.53$2.29 \mathrm{~mm}$. Excretory pore situated at the level of nerve ring. Tail length $0.16-0.20 \mathrm{~mm}$ and length of tail thorn $0.01 \mathrm{~mm}$.
Larvae of Contracaecum were encysted in walls of stomach and caecum. The size range of 20 specimens was 2.5-7.3 mm, maximum widths $0.1-0.2 \mathrm{~mm}$. Length from anterior end of body to nerve ring $0.06-0.1 \mathrm{~mm}$. Length of oesophagus $0.44-0.98 \mathrm{~mm}$, size of stomach $0.03-0.05$ x $0.05-0.07 \mathrm{~mm}$ and length of intestinal caecum 0.24 $0.8 \mathrm{~mm}$. Length of ventricular appendix $0.04-0.07 \mathrm{~mm}$. Tail length $0.09-0.17 \mathrm{~mm}$, length of tail thorn $0.005 \mathrm{~mm}$.

In the northern sampling area $\left(17-20^{\circ} \mathrm{S}\right)$ squids were infected by four helminth species: Didymozoidae mtc (100\%, 9-613), T. coryphaenae (15.4\%, 2-3), A. physeteris (23.1\%, 1-9) and Porrocaecum sp. (61.5\%, 1$21)$. Squids of the southern area $\left(34-43^{\circ} \mathrm{S}\right)$ were also infected by four species: Didymozoidae mtc (62.5\%, 6$1500)$, Scyphophyllidium sp. $(12.5 \%, 12)$, A. physeteris $(12.5 \%, 2)$ and Contracaecum sp. (37.5\%, 1-114). There were only two identical species between these two areas: Didymozoidae and $A$. physeteris. Small sample sizes from both areas prevent further investigation of the observed differences in helminth fauna composition.

\section{Discussion}

The main food of middle-sized $O$. bartramii in the southeastern Pacific included micronektonic fishes, squids, shrimps and to a lesser degree - macroplanktonic crustaceans and mollusks and nektonic squids that are the consumers of II-IV orders. The main fish group was micronektonic plankton-eaters that totaled $71 \%$ by volume. The families represented included Myctophidae, Photichtyidae, Gonostomidae, Sternoptychidae and Exocoetidae. Predatory fishes in the diet of studied $O$. bartramii were estimated to be $12.7 \%$ by volume, and they were mainly juvenile and sub-adult forms of the families Chauliodontidae, Melanostomiatidae, Gempylidae, Tetragonuridae, Idiacanthidae and Melamphaidae (division on feeding groups by Parin 1988). Cephalopods prey were represented by planktoneating octopods and squids (Enoploteuthidae, Cranchiidae and partly juveniles of thysanoteuthid and onychoteuthid squids) as well as predatory squids (mainly consumers of myctophids: middle-sized ommastrephids and onychoteuthids) (Rodhouse \& Nigmatullin 1996).

Thus this squid occupied the niche of consumer from III-IV to V orders in the open waters ecosystems of the southeastern Pacific. It is important intermediate link between large oceanic top-predators and micronektonic plankton-eating fishes (especially myctophids) and squids. The main predators of this squid are lancet fishes (Alepisaurus ferox), different species of tunas, swordfish (Xiphias gladius), marlins, active species of sharks, sperm whale (Physeter macrocephalus) and other marine 
mammals (Gaevskaya \& Nigmatullin 1976, Dunning 1998, Bower \& Ichii 2005, Young 2005).

Almost all identified food organisms are diel vertical migrants and inhabit near-surface layers at night (Parin et al. 1977, Bekker 1983, Parin 1984, 1988, Nesis 1985). Most active feeding occurs during night time at nearsurface layers (0-75 m), but squid also likely to feed during the day when their main prey migrates to depths in excess of 300-600 m. The daytime feeding at these depths was confirmed recently for $O$. bartramii in the North Pacific (Watanabe et al. 2004). In addition, this study identified the presence of the sternoptychid fish Argyropelecus affinis in diet of $O$. bartramii. This species is not involved in diel vertical migration and permanently inhabits depths of 200-600 m (Parin 1984, 1988).

Transit food organisms were relatively common but their role in squid energy metabolism is insignificant. However, their separate registration is very important for the accurate reconstruction of squid feeding behavior, size selectivity and real food relations. In order to correctly describe the taxonomy and size structure of 'proper' and transit food organisms this phenomenon requires consideration (Nigmatullin \& Toporova 1982, Nigmatullin 2005a,b). It is possible that transit food organisms facilitate the transmission of helminths from one host to another. Moreover the transit food organisms that are infected by larval helminths may potentially act as transmitters of helminthes via one trophic level (Nigmatullin 2005a).

Relative size of food organisms varied in wide limits between 0.2-77.2\% AL. But the transit food organisms occupied the minimal part of this range $(0.2-6.5 \% \mathrm{AL}$, mainly $0.5-2 \%)$. Prey that eaten directly by studied squid («proper» food) had size ranged from 3.2 to $77.2 \% \mathrm{AL}$ with optimal values between 8-25\% AL. These data on size aspect of squid food relations are first real information with using AL as standard length. Thereupon here is important to stress that the correct analysis of size relations of predator and prey, especially its comparative aspect, possible when a realistic length of the studied predator and prey will be selected (Peters 1986). The basic measurement of cephalopods is the ML (Roper \& Voss 1983, Nesis 1987). It is used as a standard length in biological investigations including studies of size relation of predator and prey. But AL is solely the natural size, and it has more veritable biological meaning than ML in special investigations of cephalopod trophic and behavioral relations including size-dependant predation. AL allows estimating real size of squid that perceives by predators, preys and other interacting animals in natural conditions.
The feeding spectrum of $O$. bartramii in this study was relatively wider in comparison with two similar-sized dominant ommastrephid squid Dosidicus gigas and Sthenoteuthis oualaniensis from open waters of the southeast Pacific, that were investigated in same period (Schetinnikov 1989, 1992, Nigmatullin et al. 1985, 2001, Nigmatullin, Shchetinnikov \& Shukhgalter $2005^{2}$ ). These distinctions are probably due to differences in the level of bio-productivity. We estimated higher abundance of nektonic squid and micronektonic fishes in the postupwelling tropical open waters (to the north of $18^{\circ} \mathrm{S}$ ) than in the subtropical waters (to the south of $18-20^{\circ} \mathrm{S}$ ) near Peruvian and Chilean EEZ boundaries (Nigmatullin et al. 1985, 1991, unpublished data). In upwelling and postupwelling communities a relatively few species of plankton-eating fishes appear to dominate whereas in lowproductivity communities the same dominance is not evident. It is likely that differences are reflected in the diet width of dominant predators in these communities (Cushing 1971, Valiela 1995).

Food composition of the mid-sized squid in this study differed from $O$. bartramii found in other parts of this species vast range on both the species and to a lesser degree the genera levels of prey identification. But preys species of $O$. bartramii by family and order levels and by their ecological characteristics are similar for all ranges. Moreover, the diet of squid ML 160-390 mm over the entire species range is dominated by the myctophids, other small plankton-eating fishes, juveniles of predatory fishes and squids with fewer numbers of large crustaceans, pelagic octopods and heteropod mollusks (Shevtsov 1972, Filippova 1974, Gaevskaya \& Nigmatullin 1976, Nigmatullin \& Pinchukov 1976, Wormuth 1976, Naito et al. 1977, Lipinski \& Linkowski 1988, Sinclair 1991, Seki 1993, Hernandez-Garcia 1995, Dunning 1998, Lordan 2001, Watanabe et al. 2004, Ivanovic \& Brunetti 2004, Bower \& Ichii 2005, Young 2005, Parry 2006, 2008).

Six species of helminths observed in O. bartramii from this study were at larvae stages and they have very broad specificity. They use various planktonic invertebrates, small fishes and squids at same stages of life cycles (Hochberg 1990) as intermediate and transport hosts. Their life cycles are realized on trophic chains of the pelagic communities and squids are infected by eating

\footnotetext{
${ }^{2}$ Nigmatullin ChM, AS Shchetinnikov \& OA Shukhgalter. 2005. Food and parasite relationships and role of mass ommastrephid squids in oceanic ecosystems of southeast Pacific. In: Libro de resumenes III Simposio Internacional sobre calamares del Pacifico y II Taller Internacional sobre calamares (28 noviembre - 2 diciembre 2005, Lima, Peru). Resumen 25: 1-3. IMARPE, Callao.
} 
infected prey - intermediate and transport hosts. The most important sources for squid infestation with larvae of cestodes, nematodes and trematodes are myctophids and other plankton-eating fishes, squids, euphausiids and shrimps (Zuev et al. 1985, Hochberg 1990). It is likely that $O$. bartramii is a transport host for these helminths, with scombroid and xiphoid fishes, sharks, marine mammals and sea birds as the definitive hosts: they are common consumers on this squid (Gaevskaya \& Nigmatullin 1976, Nigmatullin et al. 1985, Gaevskaya et al. 1986, Zuev et al. 1985, Bower \& Margolis 1991, Shukhgalter \& Nigmatullin 2001, Young 2005).

The helminths recorded in $O$. bartramii in proper open waters of the southeastern Pacific far off shelf and slope zones are the representatives of oceanic helminthes complex (Gaevskaya \& Nigmatullin 1978). Scyphophyllidium sp. is only one representative of the shelf-slope complex.

Detail comparison of our data on helminth fauna with similar data for ommastrephid squid D. gigas and S.oualaniensis from the southeastern Pacific (Gaevskaya et al. 1983, Shukhgalter \& Nigmatullin 2001, Nigmatullin \& Shukhgalter 2001) and O. bartramii from other parts of species range (Gaevskaya \& Nigmatullin 1976, Gaevskaya et al. 1986, Bower \& Margolis 1991, Nagasawa et al. 1998) is impossible due to small sample sizes in the current study. However we conclude that in general the helminth fauna composition and the levels of infestation observed in this study do not significantly differ from those other ommastrephids or $O$. bartramii populations. The differences on the level of helminth species, their number and rate of infestations are mainly due to geographical and habitat variability and influence of sample size factors.

\section{Acknowledgments}

We cordially thank S.I. Bazanov, A.V. Parfenjuk, R.M. Sabirov, A.N. Polezhaev and A.N. Golub for the collection of samples in research cruises; A.V. Gaevskaya for great help in identification of helminths, discussion and consultations; S.K. Topal and R.N. Burukovsky for help in identification of fish and shrimp remains in stomachs; W. Dimmlich and V.V. Laptikhovsky for English improving and clearing. Valuable critical comments of three anonymous referees improved the manuscript. The first author would like to thank C. Yamashiro (Instituto del Mar del Peru) for inviting and financially supporting participation at the III International Symposium on Pacific squids (Callao, Peru, November 2005) where this data was reported. This study was supported by the Russian Foundation for Basic Research, project No 06-04-49806.

\section{Literature cited}

Alexeyev OD. 1994. New data on the distribution and biology of squids from the Southern Pacific. Ruthenica 4(2): 151166.

Bakker VE. 1983. Myctophid fishes of the World Ocean, 248 pp. Nauka Press, Moscow. [In Russian]

Bower JR \& T Ichii. 2005. The red flying squid (Ommastrephes bartramii): A review of recent research and the fishery in Japan. Fisheries Research 76: 39-55.

Bower SM \& L Margolis. 1991. Potential use of helminth parasites in stock identification of flying squid, Ommastrephes bartrami, in the North Pacific waters. Canadian Journal of Zoology 69: 1124-1126.

Dunnig MC. 1998. An overview of the fisheries biology and resource potential of Ommastrephes bartramii (Cephalopoda; Ommastrephidae) in the Southern Hemisphere. In: Okutani T (ed). Contributed Papers to International Symposium on Large Pelagic Squids, pp. 6576. Japan Marine Fishery Resources Research Center, Tokyo

Cushing DH. 1971. Upwelling and the production of fish. Advances in Marine Biology 9: 255-334.

Gaevskaya AV \& ChM Nigmatullin. 1976. Biotic relationships of Ommastrephes bartrami in the North and South Atlantic. Zoologicheskij Zhurnal 55(12): 1800-1810. [In Russian with English abstract]

Gaevskaya AV \& ChM Nigmatullin. 1978. The helminth fauna of Atlantic squids of the family Ommastrephidae (Cephalopoda: Oegopsida). Malacological Review 11: 134135.

Gaevskaya AV, ChM Nigmatullin \& OA Shukhgalter. 1983. Helminth fauna of three dominant species of squids of the family Ommastrephidae from southereastern Pacific and general remarks about its formation in this family. In: Starobogatov YaI \& KN Nesis (eds). Taxonomy and ecology of cephalopods, pp. 132-134. Zoological Institute of USSR Academy of Science, Leningrad. [In Russian]

Gaevskaya AV, ChM Nigmatullin \& OA Shukhgalter. 1986. Comparative-ecological characteristics of parasite fauna of abundant species of squids family Ommastrephidae in the South-West Atlantic. In: Ivanov BG (ed). IV All-Union Conference on Commercial Invertebrates (Sevastopol, April 1986). Abstracts of reports. Part 1, pp. 337-338. VNIRO Press, Moscow. [In Russian]

Hernandez-Garcia V. 1995. Contribución al conocimiento bioecológico de la familia Ommastrephidae Steenstrup, 1857 en el Atlántico Centro-Oriental. Tesis Doctoral. Universidad de Las Palmas de Gran Canaria, Las Palmas, 307 pp.

Hochberg FG. 1990. Diseases of mollusca: Cephalopoda. In: Kinne O (ed). Diseases of marine animals, Vol. III. Cephalopoda to Urochordata, pp. 47-227. Biologisches Anstalt Helgoland, Hamburg. 
Ivanovic ML \& NE Brunetti. 2004. Diet of red squid (Ommastrephes bartramii) in the southwest Atlantic. Revista de Investigación y Desarrollo Pesquero 16: 67-75.

Lipinski M \& T Linkowski. 1988. Food of the squid Ommastrephes bartramii (Lesueur, 1821) from the SouthWest Atlantic Ocean. South African Journal of Marine Science 6: 43-46.

Lordan C. 2001. Investigations into the fisheries and biology of ommastrephid squid species in Irish waters. Ph D thesis. National University of Ireland, Cork, 272 pp.

Margolis L, GW Esch, JM Holmes, AM Kuris \& GA Shad. 1982. The use of ecological terms in parasitology. Journal of Parasitology 68: 131-133.

Nagasawa K, J Mori \& H Okamura. 1998. Parasites as biological tags of stocks of neon flying squid (Ommastrephes bartramii) in the North Pacific Ocean. In: Okutani T (ed). Contributed Papers to International Symposium on Large Pelagic Squids, pp. 49-64. Japan Marine Fishery Resources Research Center, Tokyo.

Naito M, K Murakami \& T Kobayashi. 1977. Growth and food habits of oceanic squids (Ommastrephes bartrami, Onychoteuthis borealijaponicus, Berryteuthis magister and Gonatopsis borealis) in the western Subarctic Pacific region. Research Institute of North Pacific Fisheries, Hokkaido University, Special Volume: 339-351. [In Japanese with English abstract]

Nesis KN. 1985. Oceanic cephalopods: distribution, life forms, evolution, 286 pp. Nauka Press, Moscow. [In Russian]

Nesis KN. 1987. Cephalopods of the world. Squids, cuttlefishes, octopuse, and allies, 351 pp. T.F.H. Publications, Neptune City.

Nigmatullin ChM. 2005a. The transit food relations as a potential source for predators infestation by helminthes. Bulletin of the Scandinavian-Baltic Society for Parasitology 14: 113-114.

Nigmatullin ChM. 2005b. Towards the correct methodology of cephalopod feeding study: review of some neglected problems. In: Libro de resumenes III Simposio Internacional sobre calamares del Pacifico y II Taller Internacional sobre calamares (28 Noviembre - 2 Diciembre 2005, Lima, Peru). Resumen 34: 1-3. IMARPE, Callao.

Nigmatullin ChM \& OA Shukhgalter. 2001. The macroecosystem variations of helminth fauna in ommastrephid squid Sthenoteuthis oualaniensis from Indian Ocean and East tropical Pacific. ICES Council Meeting Paper, CM 2001/K:21: 1-11.

Nigmatullin ChM \& NM Toporova. 1982. Feeding spectrum of squid Sthenoteuthis pteropus (Steenstrup, 1880) in the epipelagic of the Tropical Atlantic. In: Kuhorenko KG (ed). Food and food relations of fishes and invertebrates in the Atlantic, pp. 3-8. AtlantNIRO Press, Kaliningrad. [In Russian]
Nigmatullin ChM, KN Nesis \& AI Arkhipkin. 2001. A review of the biology of the jumbo squid Dosidicus gigas (Cephalopoda: Ommastrephidae). Fishery Research 54(1): 9-19.

Nigmatullin ChM, AV Parfenjuk \& VN Nikolsky. 1991. Ecology and resources of epipelagic nektonic squids of the Atlantic and southeastern Pacific oceans. In: Sushin VA (ed). State of the fishing industry's biological resources in the Central and South Atlantic and East Pacific. Trudy AtlantNIRO, pp. 142-177. AtlantNIRO Press, Kaliningrad. [In Russian, English abstract]

Nigmatullin ChM, RM Sabirov \& AS Shchetinnikov. 1985. Squids: Dosidicus gigas, Sthenoteuthis oualaniensis, Ommastrephes bartramii, and Thysanoteuthis rhombus. In: Fishery description of the region of the southeastern Pacific Ocean, pp. 80-88. GUNIMO Press, Leningrad. [In Russian]

Parin NV. 1984. Oceanic ichthyologeography: an attempt to review the distribution and origin of pelagic and bottom fishes outside continental shelves and neretic zones. Archiv füer Fischereiwissenschaft 35(1): 5-41.

Parin NV. 1988. Fishes of the open ocean, 272 pp. Nauka Press, Moscow. [In Russian]

Parin NV, KN Nesis \& NI Kashkin. 1977. Vertical distribution of life in the ocean. Pelagic realm. Macroplankton and nekton. In: Vinogradov ME (ed). Biology of the ocean. Vol. 1. Biological structure of the Ocean, pp. 159-173. Nauka Press, Moscow. [In Russian]

Parry M. 2006. Comparision of the feeding behaviors of two ommastrephid squids, Ommastrephes bartramii and Sthenoteuthis oualaniensis in the vicinity of Hawaii. Marine Ecology Progress Series 318: 229-235.

Parry M. 2008. Trophic variation with length in two ommastrephid squids, Ommastrephes bartramii and Sthenoteuthis oualaniensis. Marine Biology 153: 249-256.

Peters RH. 1986. The ecological implications of body size, 329 pp. Cambridge University Press, Cambridge.

Polezhaev AN. 1986. Oceanic squids of the southern part of the Pacific Ocean. Zoologicheskij Zhurnal 65(7): 994-1002. [In Russian with English abstract]

Rodhouse PG \& ChM Nigmatullin. 1996. Role as consumer. Philosophical Transactions of the Royal Society of London B 351(1343): 1003-1022.

Roper CFE \& GL Voss. 1983. Guidelines for taxonomic descriptions of cephalopod species. Memoirs of the National Museum Victoria 44: 48-63.

Seki MP. 1993. Trophic relationships of Ommastrephes bartramii during winter migrations to subtropical waters north of the Hawaiian Islands. In: Okutani T, RK O’Dor \& T Kubodera (eds). Recent advances in cephalopod fisheries biology, pp. 523-529. Tokai University Press, Tokyo.

Shchetinnikov AS. 1989. Food spectrum of squid Dosidicus gigas (Oegopsida) and its ontogenetic variability. Zoologicheskij Zhurnal 68(7): 28-39. [In Russian, English abstract] 
Shchetinnikov AS. 1992. Feeding spectrum of squid Sthenoteuthis oualaniensis (Oegopsida) in the eastern Pacific. Journal of the Marine Biological Association of the United Kingdom 72: 849-860.

Shevtsov GA. 1972. Feeding habits of the squid Ommastrephes bartrami (Lesueur) in the Kurile-Hokkaido region. Hydriobiologicheskij Zhurnal (USSR) 8(3): 77-80. [In Russian]

Shukhgalter OA \& ChM Nigmatullin. 2001. Parasitic helminthes of jumbo squid Dosidicus gigas (Cephalopoda: Ommastrephidae) in open waters of the central east Pacific. Fisheries Research 54(1): 95-110.

Sinclair EH. 1991. Review of the biology and distribution of the neon flying squid (Ommastrephes bartrami) in the North Pacific Ocean. NOAA NMFS Technical Report 105: 5767.

Topal SK. 1988. Metodological guide for identification of myctophids and another epi- and mesopelagic fishes of the Southeastern Pacific by typical skeleton elements, 147 pp. AtlantNIRO Press, Kaliningrad. [In Russian]

Valiela I. 1995. Marine ecological processes, 686 pp. SpringerVerlag, New York.
Young RE. 2005. Neon flying squid (Ommastrephes bartramii Lesueur, 1821). In: Final environmental impact statement. Seabird interaction avoidance methods and pelagic squid fishery management. April 2005, pp. 455-470. National Oceanic and Atmospheric Administration, National Marine Fisheries Service, Pacific Islands Regional Office, Honolulu.

Watanabe H, T Kubodera, T Ichii \& S Kawahara. 2004. Feeding habits of neon flying squid Ommastrephes bartramii in the transitional region on the central North Pacific. Marine Ecology Progress Series 266: 173-184.

Wormuth JH. 1976. The biogeography and numerical taxonomy of the oegopsid squid family Ommastrephidae in the Pacific Ocean. Bulletin of the Scripps Institution of Oceanography 23: 1-90.

Zuev GV, ChM Nigmatullin \& VN Nikolsky. 1985. Nektonic oceanic squids (Genus Sthenoteuthis), 224 pp. Agropromizdat Publishing House, Moscow- [In Russian, English contents]

Recibido el 18 de agosto de 2008 y aceptado el 2 de diciembre de 2008 